\title{
Land Law, Property Ideologies and the British-Irish relationship
}

Rachael Walsh and Lorna Fox O’Mahony

\section{(1) Introduction}

Land law, like the British-Irish ${ }^{1}$ relationship, is steeped in history. Yet, despite the richness of this theme, property scholarship comparing the two jurisdictions is surprisingly rare. The current Brexit negotiations provide a timely reminder of the strategic importance of property and trade relations between the two countries; and of their related-but-different legal cultures. In this article we explore how the property cultures of England and Ireland were shaped by the politics and practices of land tenure, by competing economic ideologies, and by the influence of both on national identity and statehood in both jurisdictions (Bull, 1996; Readman, 2008). Although Ireland was (euphemistically described as) the 'first adventure of the common law', Wylie observed that: '...of all the branches of the law, land law has resisted most over the centuries the influence of English common law and has retained its particularly 'Irish' characteristics.' (1997: [1.04]) Irish land lawyers are often mindful of convergence and divergence with English law, but scholars of English land law have typically paid scant attention to Irish doctrine or decisions, ${ }^{2}$ despite the powerful potential for comparative analyses to offer a fresh lens through which to recognise and understand land law's (often concealed) political and ideological commitments (Fox O'Mahony, 2014). In this article we develop a conceptual paradigm for comparative analyses of English and Irish land law. Reflecting on the complex evolution of land law norms and practices through a series of 'property moments' (Davidson and Dyal-Chand, 2010) and against the backdrop of competing economic ideologies, land reform politics, and evolving - and rupturing constitutional status, we also highlight the importance of 'mid-range' contextual analyses for property scholarship.

While English land law can reasonably claim to have its roots in the slow evolution of the common law, tracing its heritage to the feudal reforms imposed by William the Conqueror after 1066 (Dixon, 2010: 2), Irish land law has a more complex, hybrid and ruptured heritage. A story of land law and the British-Irish relationship might begin with the Norman Conquest of Ireland in 1171-2, and attempts to impose English common law over native Irish (or Brehon) law (MacNiocaill, 1972); with the confiscation and resettlements of Irish land by British forces in the $16^{\text {th }}$ and $17^{\text {th }}$ centuries (Delaney, 1959); or with the 'Penal Laws' that prohibited Irish Catholics from owning Irish land in the $18^{\text {th }}$ century. This article starts with the period that followed the 'Great Hunger' of 1845-47. The Irish Famine is widely recognised as a cataclysmic event (Daly, 1986; Portier, 1995; Kinealy, 1997), with major and lasting implications for political, economic and social life and thought in Ireland, and for the constitutional relationship with Britain. Land reform dominated the British-Irish relationship and Irish land law and politics throughout the nineteenth century. And, as the industrial revolution, the emergence of modern capitalism and the rise of liberal individualism fundamentally reconfigured property relations in England, shifting the nature and location of

\footnotetext{
${ }^{1}$ In this paper, we use the terminology of 'Britain' to refer to the political and constitutional entity of Great Britain, and the outward-looking property perspective of the British Empire; 'England' to refer to the legal jurisdiction of England and Wales, and the more inward-looking 'Englishness' of liberal individualism, Victorian social morality and popular and domestic associations between land and national identity; and 'Ireland' to refer to the island of Ireland before, and within, the United Kingdom of Great Britain and Ireland, and the independent Irish state after 1921.

${ }^{2}$ Although the professional press has noted a 'tsunami' of English solicitors seeking admission to practice law in Ireland in anticipation of 'Brexit'; https://www.thelawyer.com/issues/online-december/brexit-uncertaintyprompts-800-english-lawyers-join-irish-roll/ (accessed 5 February 2018).
} 
power in society from landed aristocracy to capitalist democracy - from status to contract (Maine, 1861) - English land reform campaigners echoed the tenets of the Irish movement. As the emergence of modern class structures prompted fresh agitation for collectivist/social democratic land reforms, the rise of land tenure resistance and radicalism within Britain (Cragoe and Readman, 2010) only raised the stakes on the Irish Land Question for the British Government (Cragoe, 2010). In 1880, Conservative Prime Minister Disraeli told the House of Lords that 'the two subjects which most occupy the thought of the country at the present moment [are] the government of Ireland, and...the principles upon which the landed property of this country should continue to be established.' (Perkin, 1973: 177) The two issues clashed when Liberal Prime Minister Gladstone launched his programme of support for Irish Home Rule in 1886; and the English land reform movement collapsed in the rift that split the Liberal Party over Ireland (ibid: 178). Land reform was a prominent issue in nineteenthcentury politics, as England's transition to modern capitalist democracy re-shaped other areas of property law, contract and commercial law. Yet, as Dicey observed in 1905, 'the fundamentals of land law remain unchanged. They were in 1900, they still are today, what they were in 1800, or indeed what they were in the time of Blackstone' (Dicey, 1905: 221-2).

Ireland's status as a former British colony is an important factor in comparative analyses of land law and politics in the two jurisdictions. The politics of land reform has particular salience in post-colonial settings, as newly-(re)constituted states grapple with legacies of imposed colonial land tenure systems and displaced native land governance (Njoh, 1998; Mamdani, 1996; Peterson, 2012; see section 3), and the state-making challenges of forging a new land law and politics for a new constitutional order. English land law, in contrast, has a different order of intellectual and ideological heritage. Property ideologies (for example, Lockean labour theory: Arneil, 1996; laissez-faire capitalism and free trade in land: see section 2) deployed to justify the structures of power through which the British Empire exercised state sovereignty over colonised territory (Koskenniemi, 2017: 389) influenced the conceptual frameworks of private property, and land reform politics, in England. As Ireland slowly transitioned from colony to independent state - from the Act of Union 1800 to the creation of the independent Irish Free State from 1921 - it is unsurprising that the 'Irish land question' took centre-stage in the contested British-Irish relationship. ${ }^{3}$ After independence, Irish land law continued to rest on the foundations of imported English common law, but this was overlaid with constitutional, legislative and judicial developments to create a new modern Irish land law. Indeed, it was not until the Land and Conveyancing Reform Act 2009 that Ireland finally abolished the remnants of the transplanted English system of feudal tenure.

This article focuses on the role of property ideologies - and, crucially, the local contexts in which they are articulated and applied - in constructing land law systems. Much current debate in property scholarship tends to bifurcate between 'grand theories' (often polarised as 'conservative/libertarian' or 'progressive/communitarian' justifications or critiques of private property, and advancing normative prescriptions for legal interpretation and development, c.f. Merrill, 1998; Merrill and Smith, 2007; Penner, 1997, Katz, 2008; Alexander et al, 2009; Singer, 2009; Baron, 2010) and 'earthily pragmatic' land law doctrinalism - reflecting what Gray and Gray described as a 'deeply anti-intellectual streak in the common law tradition which cares little for grand or abstract theories of ownership' (1998: 18). Our approach departs from these methods by developing a 'mid-range theory' (Merton, 1949). Theories of

\footnotetext{
${ }^{3}$ Following the Act of Union of Great Britain and Ireland 1800 Ireland formally ceased to be a colony, although McDonough (2005) argued that the relationship continued to bear the features of colonial rule throughout the nineteenth century.
} 
the middle range 'lie between the minor but necessary working hypotheses that evolve in abundance during day-to-day research and the all-inclusive systemic efforts to develop a unified theory...' (Merton: 448) They seek not to build a 'general and definitive framework', but rather to 'guide the investigation of specific...problems within an evolving and provisional framework', 'tackl[ing] problems one at a time' (Merton: 453). The complexities of the British-Irish relationship over eight centuries; the evolution of economic thought in both countries, with implications for political, jurisprudential and popular understandings of the nature of property; the intersections between land ownership and sovereignty, statemaking and national identity; and the ongoing impact of these histories for both domestic law and politics and the regional context of the European Union and Brexit; require a carefully grounded approach to comparative legal analysis. As van der Walt and Walsh note in the context of comparative constitutional property law, there must be: '...close attention to jurisdictional differences, and to broader social, economic and cultural considerations not always apparent from the face of constitutional texts, legislative provisions, or even judicial decisions' (van der Walt and Walsh, 2017).

Despite their shared history and influences - from the transplant of the common law system to Ireland to traditions of training Irish lawyers and judges in English universities - the politics of property led Irish and English land law down distinctive ideological paths in the twentieth century. This article reveals the role of local contexts and events in shaping land reform, and demonstrates the fertile potential of the comparative frame to contextualise each jurisdiction's doctrines and practices. As domestic land law systems are drawn together in the context of emerging EU jurisdiction over areas like mortgage credit, each jurisdiction's underpinning ideological commitments have important implications for the ease - or not - of attempts to harmonize member state practices. The alignments and divergences between the domestic underpinnings of Irish and English law (and their 'family resemblances' to other EU member states: Kenny, 2007) take on heightened significance for the continuance of crucial economic and political relationships between the UK and Ireland, and particularly across Northern Ireland's land border between Ireland/EU and the UK, in the context of a post-Brexit scenario.

\section{(2) Framing the Land Question(s) in Ireland and England}

The English common law system was transplanted to Ireland through processes of conquest, confiscation and re-settlement. It replaced the native Brehon system with English settlor landlords, creating 'a kind of bastardised feudalism... a feudalism not founded in a history of the evolution of mutual rights and obligations between a native peasantry and a native (or at least assimilated) ruling class' (McDonough, Slater and Boylan, 2005: 213). The effectiveness of the imported system was limited by the legacies of colonial conquest, and the absence of common allegiances of religion or nation, or conventions of deference, between tenants and landlords. The feudal land system, with its roots in aristocratic landlord-status and tenant-service, came under pressure across the UK in the nineteenth century (Howe, 2010; Thompson, 2002). However: 'without a system of mutual rights and obligations, agrarian relations within the Irish estate suffered from a more radical schism than existed in landlord/tenant relations in mainland Britain' (Howe, 2010: 213). Indeed, radical English land reform campaigns in this period regarded Irish land reform - where the particularities of the local context had seeded fertile ground - as a necessary precursor to English land reform (Cobden, 1835; Mill, 1868). However, local factors in England - including English perceptions of agrarian violence in Ireland, and, later, Liberal-Conservative alignment in support of 'free trade in land' - meant at the moment Irish land reform was achieved, the 
conditions for land reform in England fell away, and campaigns for state-intervention in land distribution foundered in favour of reliance on market forces to effect any redistribution of land.

\section{(a) Land conquest, control, and competing notions of proprietorship}

The evolution of Irish land law in the nineteenth century provides a paradigmatic example of what Gray and Gray described as: 'the normative structure of legal phenomena as a product not only of collaborative human endeavour, but also of a creative tension between formal and informal sources of law.' (Gray and Gray, 2003: 206). In 1845 the Devon Commission, reporting on the 'State of the Law and Practice in Respect of Occupation of Land in Ireland', acknowledged the continued prevalence of native land tenure practices and the effects of these practices in shaping the popular ideology of property. Notwithstanding the formal imposition of English common law, by the $19^{\text {th }}$ century, no formal leases were issued in Ireland, and 70-75\% of tenants were informal yearly tenants or tenants-at-will (Solow, 1971: 7). Despite this absence of formal legal relationships, the practice of 'Ulster Custom' or 'tenant right', whereby 'a tenant, upon leaving his holding for whatever cause, claimed the privilege of exacting from his successor a sum of money running up to ten or fifteen years' rent' (Dunning, 1892: 59); had generated: 'a feeling of proprietorship [that] had grown up in the tenants which was wholly anomalous in reference to ordinary [English] notions of property.' The Devon Commission acknowledged the strength and depth of Ireland's practiced land norms; however, its recommendations aligned to the British ideologies of absolute property rights and laissez-faire capitalism. Collinson Black argued that the British ideology of: "treating the non-renewable resource of land as a commodity...lay at the heart of the Irish problem, since it involved violent offence to native perceptions of the occupier's relationship to the land' (1960: 28-29). While Irish custom regarded tenants as having a proprietary stake in the land by virtue of their occupation, English property ideology required that: '...the 'owners' of the land [not the tenants] are indeed its owners in absolute terms, with the right to sell or lease as they pleased and at whatever price allowed by the market' (Bull, 1996: 11).

The British Government's first legislative intervention in Irish land after the Famine was the Encumbered Estates Acts 1848 and 1849, which established Encumbered Estates' Courts with authority to sell mortgaged estates where estate owners were unable to meet their financial obligations. The aim of these Acts was to attract English capital investors to fund the 'modernisation' of Irish agriculture, redistributing Irish land amongst a new cohort of private landlord investors, and helping landlords assert themselves more strongly as the providers of capital and promoters of prosperity and order in the countryside. ${ }^{4}$ The legislation made no provision for tenants; its purpose was to force the transition to laissez-faire capitalist principles and practices in Ireland, to: '...facilitate various long-desired changes...The government measured the success of its relief policies by the changes which were brought about in Ireland rather than by the quality of relief per se' (Kinealy, 1994: 353). The Landlord and Tenant Law (Amendment) Act (Ireland) 1860 ('Deasy's Act') was a further attempt to embed the principles of laissez-faire capitalism in Irish land law, expressly rejecting customary Irish practices and declaring that the relationship between a landlord and a tenant was based in contract, not property. Historian Philip Bull argued that Deasy's Act only highlighted the incompatibilities of British and Irish property cultures, because it:

\footnotetext{
${ }^{4}$ The Encumbered Estates' Court, created under the 1849 Act, was replaced by the Landed Estates Court and then in turn by the Land Commission, discussed below.
} 
'declared that what was coming increasingly to be seen as the reality of Irish land tenure was in fact not so... The Act made explicit in law the assumptions of English landed society, restating the absolute rights of ownership vested in the landlord, clarifying the contractual nature of the relationship with the tenant, and strengthening the powers of the landlord in relation to eviction' (Bull, 1996: 44).

Deasy's Act, with the Tenure and Improvement of Land (Ireland) Act 1860 (Cardwell's Act), was intended to: "close for all time the question of differential land laws in Ireland...to complete the process...by which the absoluteness of the landlord's ownership was secured and obstructions...to 'free contract' removed' (ibid, 44-45). Introducing his Act, Irish Secretary Cardwell stated: '[w]e should not interfere with the power of the landlord...we should reserve to him the right of objecting to improvements... we cannot violate the law of property. ${ }^{5}$ Bull claimed that: 'the confident English assumption [was] that the spirit of Irish native culture could be subdued to the letter of British law and the tenets of British economic ideology' (Bull, 1996: 44-45).

\section{(b) Shifting economic environments and perspectives}

The transition from feudalism to capitalism, and its impact on the ideologies of use and ownership of land, was also a source of considerable debate within Britain during this period (Cragoe and Readman, 2010). In Britain (and elsewhere), the economic opportunities of industrialisation, the developing market economy, and relatively greater social and cultural common ground between landlords and tenants, aided the transition to a property rights culture based on market relationships (in place of paternalism) and laissez-faire capitalism (in place of feudalism). But while nineteenth century Britain advanced its global economic hegemony through the new 'Atlantic economy' (O'Hearn, 2005), Ireland remained overwhelmingly agrarian. ${ }^{6}$ Although markets, trade and monetisation existed in Ireland (Solow, 2013: 69), the dampening down of Irish industrial development meant tenants remained tied to the land. At the same time, by 1870 only $3 \%$ of the population of Ireland owned land (McDonough and Slater, 2005: 28), and British legislative intervention had stripped back tenants' rights. In mid-nineteenth century England, a mass rural exodus of workers to towns had shifted the means of production to newly capitalised industrial ventures, reducing dependency on the land (Perkin, 1969: 38-56), and focusing economic growth on the values of competition, entrepreneurship, and 'self-dependence' (Mill, 1904). The capitalist norms of industry and work were becoming embedded (and contrasted with the paternalism and 'idleness' of the aristocracy); and the new 'entrepreneurial ideal' underpinned campaigns to abolish protectionist and monopolistic economic practices. This "inevitably extended...to "free trade in land" [and] the abolition of the devices by which the landowners kept the great estates together in a few hands' (Perkin, 1969: 229).

While Britain recalibrated its property ideologies to the philosophies of entrepreneurialism, independence and economic individualism, Irish economists of the historicist school took a different view of state intervention to protect tenants, which emphasised Ireland's economic dependency and the historic role of the British state in creating those conditions through

\footnotetext{
${ }^{5}$ Hansard ( $3^{\text {rd }}$ Ser) CLIX, col 2145 (19 July 1860), CLVII, col 1564 (29 March 1860), quoted in Steele, 1974: 68.

${ }^{6}$ In 1841, almost three-quarters of the occupied male workforce were engaged in farming, compared to under a quarter in Britain; McDonough and Slater (2005) citing Hoppen (1992), Deane \& Cole (1969), p142. For an overview of reasons for this difference see O’Malley (1981).
} 
British economic protectionism. Cliffe Leslie (1870) described the Irish land reform movement as a demand for the post-colonial restoration of tenants' property rights:

'The landholders of Ireland are not only, in the same sense as those of England, the creatures, the tenants of the state, but they are the creatures of a violent interference with pre-existing rights of property. Moreover, by further violent interference in the shape of penal laws, directed expressly against industry and accumulation on the part of the bulk of the people, and precluding the acquisition of property and capital and the rise of other industries, the state forced the great mass of the population to become competitors for the occupation of land as a means of subsistence...Instead of the conditions to which the maxim of non-interference applies, is a system of interference which has made the landlord independent of all exercise of frugality and improvement, and deprived the tenant of all security for it' (128-9).

Although Ireland was technically no longer a colony after the Act of Union 1800, the enduring impact of the Penal Laws (which included barring Irish Catholics from owning land or engaging in the professions); the Navigation Acts (through which Britain protected English trade and controlled Irish agricultural practice by excluding certain Irish products from English and other foreign markets); and the Corn Laws (through which British grain prices were protected by heavy tariffs on foreign-grown grain) had ensured England's trade dominance, and Ireland's ongoing dependence (O'Hearn, 2005). O'Hearn argued that, until independence in 1921, British policy 'integrated Ireland in a subordinate position within its strategy for creating an Atlantic economy' (p4). As in other peripheral economies (Senghaas, 1985: 14), Irish trade dependency slowed the pace of industrialisation in the nineteenth century; maintaining its predominately rural, agricultural economy (McDonough, Slater and Boylan, 2005), and incentivising insecure tenure and short leases, since the shifting demands of trade with England discouraged sunk investment and long term commitments by landlords (Boylan and McDonough, 2005). Even after Independence, the need to preserve, and if possible expand, agricultural export markets, particularly cattle trade, guided Irish land reform policies towards protecting large farmers (Dooley, 2004: 61-62; 91-92). ${ }^{7}$ Indeed, Ireland's trade exposure on agri-food exports to the UK has been a prominent concern in the current Brexit debates (DGIP, 2017: 39).

The Famine triggered an important turning point in Irish economic thought, ${ }^{8}$ which simultaneously became more outward-looking (Famine-era paths of emigration from Ireland to America had seeded an 'Irish nation abroad', creating a route for alternative ideas to travel back to Ireland, and adding another international dimension to the evolution of Irish ideologies, which were already influenced by political developments elsewhere in Europe) and more explicitly focused on the unsuitability of laissez-faire economic principles to respond to the material realities of local needs (McDonough, Slater and Boylan, 2005). Before the Famine, influential Irish economists like William Hancock argued that the incongruence between Irish land practices and laissez-faire theories mandated a more vigorous application of English political economy - including the removal of legal impediments to the unfettered operation of the market (Hancock, 1847: 3; Hancock, 1848;

\footnotetext{
${ }^{7}$ Edgeworth (2007:8) notes that agricultural production grew considerably during the first decade of the Irish home rule.

${ }^{8}$ Boylan and McDonough (1998: 113) claim that: 'Before the famine, classical political economy based in a utilitarian framework and advocating a policy of laissez-faire, was dominant in Ireland both at the level of the academy and in attempts at popular education in economic matters...After the famine, classical political economy in Ireland was largely abandoned and alternative frameworks of thought were sought.'
} 
Hancock, 1850). However, from 1855, Hancock adopted a more social ideology, incorporating moral concerns about the impact of laissez-faire economics in the Irish context, and with particular regard for women, families and the home (Hancock, 1860a; 1860b) - later echoed in Articles 41.2 and 45 of the 1937 Irish Constitution). In 1859, he wrote that:

'The care of wealth has now, as ever, a tendency to hardness of heart, which moral discipline is necessary to control. It has, too, a tendency to generate strong selfishness and a want of consideration for others...social science does not sanction any law of competition as a substitute for the important moral duties that devolve on every owner of wealth and every employer of labour' (Hancock, 1859: 381).

This social-relational perspective penetrated the Irish constitutional treatment of property, discussed in Part 3. The Irish social vision of property, with its emphasis on 'consideration for others', the moral duties on owners and employers and human interdependence, can be contrasted with the puritan English Victorian morality that, reflecting British economic ideology in the late nineteenth-century, emphasised individual endeavour and hard work, and (with an eye to aristocratic landowners) characterised idleness and waste as anti-social and immoral (Perkin, 1969: 287-8). As we demonstrate in Part 3, this schism between Irish and English contexts - reflecting economic and social norms as these were shaped in response to local land use patterns, practices and politics - has had a lasting impact on the property cultures and 'land law values' of each jurisdiction.

\section{(c) Land, National Identity and Class}

According to O'Tuaithaigh (2013: 16): '[t]here was never a single 'Irish land question', but a dense matrix of interlocking issues and questions relating to the story of land in Ireland.' While some of these issues (for example, the emergence of new class structures in the transition from status-based aristocracy to contract-based capitalist society; and the influence of collectivist/socialist ideologies in the nineteenth century) were paralleled in the English experience, other factors were distinctively different (for example, the pace of industrialisation, and the impacts of independence/dependence, and free trade/protectionism, on economic development). In Ireland, the publication of the first of six volumes of The Ancient Laws and Institutes of Ireland by the Brehon Law Commission in 1865 was a watershed moment for the socio-cultural revival of Ireland's native, pre-Conquest legal heritage. ${ }^{9}$ The cultural-nationalist expression of the Irish land campaign emphasised the united opposition of all sections of Irish society to the Protestant landed ascendency. Bull argued that this cultural nexus between a shared Irish heritage and national identity and the land reform campaign became 'so important in national life that it shaped the future of Irish nationalism and the shape of the society which emerged out of the nationalist struggle, creating between the issues of land and nationalism a nexus which was so strong that the one issue became effectively a metaphor for the other' (Bull, 1996: 4).

In England, late-nineteenth-century calls for 'free trade in land' reflected the rise of the capitalist middle-class against the landed aristocracy and resonated with a version of English national identity that emphasised individualism, self-reliance and personal liberty (Readman, 2008: ch 3). While the ideology of private property had already performed a foundational role in British ideas about Empire - justifying the exercise of sovereign power in America and elsewhere (Koskenniemi, 2017; Arneil, 1996) - Readman has distinguished between the

\footnotetext{
9 A British Royal Commission was appointed in 1852 to supervise the transcription and translation of the Brehon Laws (Ancient Laws and Institution of Ireland) published in 6 volumes from 1865-1901; subsequently annotated by Professor Binchy as Corpus Iuris Hibernici (1979).
} 
'outward-looking Britishness' of Empire, and the 'inward-looking Englishness' that 'focused on insular patriotic concerns and conceptions of national belonging... [c]ultural concern with land, landscape and the rural... based on the maintenance of a sense of continuity with an imagined English past' (Readman, 2008: 212). Readman demonstrates how these ideals of land and nation resonated across the political spectrum, re-interpreted and incorporated in the rhetorical claims of Conservatives, Liberal and Labour alike. National identity was woven into each party's 'call to action' for land reform, although in England (in contrast with Ireland and continental Europe), ${ }^{10}$ individualism, laissez-faire non-intervention, and gradual reform through market forces ('free trade in land', as enshrined in the '1925 legislation', discussed in Part 3(b) below) resonated more strongly with images of English nationhood than calls for direct redistribution. In addition, the English context was foreshadowed by events in Ireland: reflecting on the resilience of established land law norms and practices, Dicey highlighted the absence of revolutionary violence in the English land campaign (and the anxiety provoked in England by reports of violent agitation in Ireland, which dampened popular support for radical change), as well as the conservative tendencies of the conveyancers who were the gatekeepers to realising peaceable reform (Dicey, 1905: 223). ${ }^{11}$

The second half of the nineteenth-century is often considered the 'classical' period of English private law, ${ }^{12}$ when the common law embedded the liberal philosophies of individualism, limited government intervention, and a 'ruling principle at common law [of] freedom of enterprise' (Wagner, 1953: 44). The ideologies of economic liberalism had re-shaped contract law (Atiyah, 1979), liberating trade and commercial property transactions to market forces, and liberal-capitalist reformers campaigned to re-shape land law in accordance with the economic imperative, and socio-moral values, of 'free trade in land'. In the English context, the campaign for 'free trade in land' was focused on liberating real property from aristocratic estates, opening up the market in land to middle-class capitalism and - from the turn of the twentieth century - the possibility of peasant proprietorship through market forces. These factors would also come to prominence in Ireland, particularly after independence: as we explore further in Part 3, the land campaign also cut across a 'class struggle' within Ireland; ${ }^{13}$ between large and small farmers, and between farmers and agricultural labourers. ${ }^{14}$ But, while the Irish context (and, particularly, the history of British intervention in Irish land tenure and the post-colonial campaign to restore land ownership to the Irish people) fuelled political and popular calls for state-led redistribution, in England, the political value of liberal non-interventionism steered the outcome towards market-led redistribution. As we demonstrate below, these contextual distinctions have had a lasting influence on contemporary English and Irish land law.

\footnotetext{
10 'Nor is it at all clear that the mass of the English people are possessed by that vehement desire for the ownership of land which is certainly common in some continental countries, and in Ireland, if one may believe the best authorities, amounts to a passion' (Dicey, 1905: 224-25).

${ }^{11}$ On the role of legal professionals in English land law reform campaigns, see Offer (1981); Anderson (1992).

12 According to the classical construct, law's atomistic version of individualism was the only available social construct in late nineteenth century legal narratives, with competing social alternatives - status and collectivism - constructed as other; although this is challenged by Rosenberg (2013).

${ }^{13}$ Paul Bew has argued that accounts of the Irish Land Wars as a feature of the larger historical struggle - as 'the militant consensus of a risen people' - are a myth; and that the conflict is better understood as a civil war amongst the Irish themselves, between large and small farmers, and between farmers and agricultural labourers (Bew, 1979: 220).

${ }^{14}$ McDonough et al asserted that while TE Cliffe Leslie was an historicist, he was not an Irish nationalist; his advocacy of 'peasant proprietorship' was concerned with the transformation of class relations within Ireland; 'substituting a countryside dominated by sturdy yeomen proprietors for one in which peasants live in thrall to hereditary landlords' (McDonough, Slater \& Boylan, 2005: 223-4).
} 


\section{(d) Compromise and concessions}

The native Irish concept of tenants' rights, the 'Ulster custom' (albeit in a diluted form), ${ }^{15}$ was recognised in Gladstone's Land Act 1870. Compared with Deasy's Act and Carswell's Act, this marked a significant turning point in British policy on Irish land law. Yet, despite the compromises in the 1870 Act - both in re-configuring the substance of property values to row back on the absolute rights of owners, and in permitting Irish land law to depart from English norms - it did not satisfy the broader aspirations of Irish tenant farmers. In 1881, the first Irish Land Act marked a further departure, by introducing a concept of 'peasant proprietorship' or 'dual ownership', 'predicated on an assumption of shared responsibility between landlord and tenant and of a co-operative approach to both agricultural and social questions' (Bull, 1996: 90). The concessions set out in these Acts fundamentally breached the principle of sovereign private property rights that Britain's 'free trade Empire' was built on, decisively rejecting the 'official' economic ideology of laissez-faire capitalism and further differentiating land law relationships within the United Kingdom of Great Britain and Ireland, on the principle of local context.

While Gladstone's concessions yielded to the Irish social conception of land occupation, the political context in which the compromises emerged had rendered cooperation between landlords and tenants in Ireland no longer credible. The context of the Irish land reform movement had successfully mobilised popular opposition to the status quo of established property rights, and forged the link between Irish sovereignty and Irish land ownership. Despite British concessions to recognise the social basis of land occupation in Ireland, and against a backdrop of rising nationalism, anti-landlordism, and class struggle, the Irish reform movement refocused its campaign on tenant ownership through land purchase schemes. As the Irish land campaign was subsumed within the wider nationalist campaign, Gladstone's decision to support Irish Home Rule triggered the rupture of the Liberal Party; dashing the hopes of more radical English land reformers that English land law would follow the Irish model. The campaign for English land reform was lost in the rift that split the Party (Perkin, 1969: 178).

Continued agitation through the 1880s and 1890s led to a series of Acts between 1885 and 1903 to facilitate the purchase of land by tenants, funded by loans from the British Treasury. The paradoxical outcome of leasehold enfranchisement was that: 'the most effective sociopolitical movement of collective action in modern Irish history...[led to] the entrenchment of a decidedly individualistic system of farm ownership' (Ó Tuathaigh, 2013: 17). This statesponsored land purchase programme created a sizeable native owner-occupier class, which (anticipating the English Conservative Party's strategies of free trade in land in 1925, and widespread homeownership after 1979) became a bulwark against (further) radical social transformation (Garvan, 1996). It created a second strand in Irish land politics, geared around native ownership which, alongside the social property norms discussed above, would animate Irish land politics, and influence the development of Irish land law, into the twentieth century.

\section{(3) Twentieth-century turning points in English and Irish Land Law}

The politics of land ownership remained prominent in both England and Ireland in the early $20^{\text {th }}$ century, shaping the foundations of contemporary land law regimes in both jurisdictions.

\footnotetext{
${ }^{15}$ Diluted from 'peasant proprietorship' to liability to compensate for improvements.
} 
In the Irish context, land ownership was synonymous with newly-won independence, and the post-independence state-making process offered the opportunity to give constitutional expression to these values. Pragmatically, the economic sustainability of rural, agricultural life was crucial to the newly-independent nation, and land redistribution remained a prominent political issue, influencing legal reform and creating tensions between the expansion and limitation of private ownership at the local and national level. The memory of the hardship of the Famine and the exclusionary structure of private ownership under the feudal system and the Penal Laws continued to resonate strongly with the Irish people as they set out to construct an 'independent' system of land law. Meanwhile, in England, the 1925 legislation marked the culmination of a wave of land law reform that promised to deliver the ambitions of 'free trade in land' through greater efficiency, streamlined conveyancing and heightened protections for investors and purchasers of land.

\section{(a) Property, Land Redistribution and Social Justice in Ireland}

The land question in all its complexities resonated throughout the period of Irish independence and the formation of the newly independent Irish state. By the early $20^{\text {th }}$ century, in the wake of leasehold enfranchisement, the role of private property rights in meeting the need for secure possession of land and other essential resources was firmly framed within the national psyche. JJ Lee (1989) argued that, for the Irish people, 'an obsessive attachment to land' was driven by a need for security in the face of uncertainty. Lee contended that:

'this attachment was not fundamentally to land for its own sake, though land could come to inspire an intense emotional identification through acquired family associations. Land was equated with security... [and t] he concern with property rights was wholly natural in the light of the alternatives facing the holders of land or jobs.' (Lee, 1989: 390-1)

This 'possessor principle', which 'owed its power not to the whims of individuals, but to attitudes deeply rooted in social structure and historical experience' (Lee: 390), was highly influential in Irish culture until at least the second half of the twentieth century (392). Demand for secure possession of property, as well as the need to ensure economic sustainability in agriculture, underpinned widespread popular support for land redistribution (Cullen, 1987: 134-71), which was also politically intertwined with Irish nationalism (Dooley, 2004: 32-39). The Land Purchase Acts, particularly the Land Law (Ireland) Act 1881 and the Land Acts of 1903, 1909, 1923 and 1933, empowered the Land Commission (a statutory public body under Ministerial control) to compulsorily acquire land for redistribution to tenant farmers and to owners of uneconomically small farms. Transferees received acquisition loans from the Land Commission, and compensation was paid to dispossessed owners on progressively more attractive terms, to encourage cooperation (Dooley, 2004: 66-71).

Beyond its association with Irish nationalism, land redistribution was also framed in terms of a social justice movement: property rights were valued not in the abstract but for the economic security that they would bring to precarious occupiers, with state intervention regarded as a legitimate mechanism to achieve wider distribution of land. Brian Walsh argued that the social-justice frame surrounding of land redistribution led the Irish people to place less emphasis on ownership than elsewhere in the English speaking world (Walsh, 1980: x). Yet, the land-reform programme created a growing population of 'highly conservative small owner-occupier farmers' (Chubb, 1970: 15) who, in turn, embraced the 'possessor 
principle'. ${ }^{16}$ Land reform extended the reach of private ownership, under the auspices of social justice, while also embedding political support for the norm of expropriation of land for public purposes, including through private-to-private transfers. This ideological duality commitment to private ownership and to state intervention to secure social justice fundamentally shaped the Irish constitutional treatment of property.

\section{(b) Irish Independence and the 1922 Constitution}

Following the Irish War of Independence (1919-1921), the peace negotiation was given effect in the Anglo-Irish Treaty. This was adopted in the UK through the Irish Free State (Agreement) Act 1922, approved by Dáil Éireann on January 7, 1922, and ratified through the Constitution of the Irish Free State (Saorstát Éireann) Act 1922. The Irish Free State was born, with the status of Dominion of the British Empire; and the process of drafting a Constitution, subject to the terms of the Treaty, was undertaken. ${ }^{17}$ Although, ultimately, the only provision of the 1922 Constitution to address property rights was Article 11 (State's rights over natural resources ${ }^{18}$ ), the nature of private property rights received extensive consideration during the drafting process. Archival analysis of this process reveals a strongly communitarian property ideology, reflected in substantial political support for a sociallyoriented approach to constitutional property rights protection.

The Constitution-drafting process marked a significant and deliberate point of departure from the UK's legal system. Kohn noted that: '....theoretical inclination and republican outlook alike led the drafters to seek inspiration from Continental models, however experimental, rather than from the empirical framework of the British Constitution' (Kohn, 1932: 78). The Constitution drafting committee - given one month in which to complete its work (Cahillane, 2014: 8) - proposed three complete draft constitutions (drafts A, B and C), ${ }^{19}$ each of which articulated a constitutional vision of private property and its relationship with the common good. Drafts A and B addressed these questions in almost identical terms; Draft C took a different approach. While Draft $\mathrm{C}$ was not adopted, its structure appears to have informed the property clause adopted in 1937 Constitution (considered further below). All three drafts illustrate political consensus that the Irish Free State's approach to property would not follow the exclusionary norms of English law, but pursue a more social or communitarian outlook.

Article 1 of Draft A (and Draft B, which contained an almost identical version of Article 1) was clearly inspired by the socialist revolution that precipitated independence. Under a section headed "Fundamental Rights" it provided that:

\footnotetext{
${ }^{16}$ The tension between the initial demand in Irish society for land redistribution and reform, and the subsequent desire for secure property rights, is highlighted by Kelly, 1967: 172-3.

17 As Kohn notes, through this process, "[t]he conflict between English formalism and Irish dogmatism was transferred to the technical sphere of constitutional detail, but it lost none of its intensity' (Kohn, 1932: 7).

${ }_{18}$ Article 11: "All the lands and waters, mines and minerals, within the territory of the Irish Free State (Saorstát Eireann) hitherto vested in the State, or any department thereof, or held for the public use or benefit, and also all the natural resources of the same territory...shall...belong to the Irish Free State (Saorstát Eireann), subject to any trusts, grants, leases or concessions then existing in respect thereof, or any valid private interest therein... [and] shall not, nor shall any part thereof, be alienated, but may in the public interest be from time to time granted by way of lease or licence to be worked or enjoyed under the authority and subject to the control of the Oireachtas..." This represented '...only a very incomplete realisation of the socialistic postulates of the "Democratic Programme" of 1919', although it could have potentially facilitated a progressive nationalization of natural resources: (Kohn, 1932:172-174).

${ }^{19}$ National Archives of Ireland, Department of an Taoiseach File S/8953 and National Archive Boxes on the Constitution Committee 1922.
} 
'The Nation's sovereignty extends not only to all the men and women of the nation, but to all the material possessions of the nation, the nation's soil and all its resources and all the wealth and wealth-producing processes within the nation. All right to private property is subordinated to the public right and welfare of the nation. It is the duty of every man and woman to give allegiance and service to the commonwealth, and it is the duty of the nation to ensure that every citizen shall have opportunity to spend his or her strength and faculties in the service of the people. In return for willing service it is the right of every citizen to receive an adequate share of the produce of the nation's labour. 20

In contrast to the English political and professional class of this period: '[s]ocialism was not necessarily feared by the framers of the 1922 Constitution. The 1916 Proclamation had declared the "right of the people of Ireland to the ownership of Ireland"; and the 1919 Democratic Programme issued by Dáil Eireann repeated that declaration and reaffirmed "all right to private property must be subordinated to the public right and welfare" (O'Donnell, 2008: 417). ${ }^{21}$

In drafting the clause, the Committee appear to have been influenced by the property clause of the USSR Constitution, which was included in Select Constitutions of the World, ${ }^{22}$ a book compiled by the Constitution Committee to supporting the drafting process. The USSR Constitution provided that:

'[i]n order to establish the socialisation of land, private ownership of land is abolished; all land is declared national property, and is handed over to the workers, without compensation, on the basis of an equitable division, carrying with it the right to use only';

and required that everyone carry out 'work useful to the community'. While Article 1 of Draft A did not follow the Soviet model of abolishing private ownership, it gave private property rights no weight above claims of the common good, and imposed duties of cooperation and contribution on individuals in return for a right to share the common wealth. This reflected the Constitution Committee's commitment to a social and communitarian property ideology, framed in terms of the collective interest in social justice, rather than in terms of individual rights.

While Draft C did not subordinate private property rights entirely to the common good, its basic outlook remained communitarian: for example, Draft Article 62.1 provided that: '[t]he right to hold private property, like other rights, implies a correlative duty, and it must not be exercised to the detriment of the community'. Property rights were dealt with under Part IX, "Economic Life", which contained principles of social policy, individual rights and duties

\footnotetext{
${ }^{20}$ National Archives of Ireland Department of an Taoiseach File S/8953.

${ }^{21}$ See also English (2000: 84) acknowledging the socialist-republican argument: '...that the struggle between the oppressed nation (Ireland) and the oppressor nation (England) is necessarily interwoven with the struggle within Ireland between those classes oppressed by capitalism and those which benefit from it.' English goes on to note that the ambitions of those advancing this argument were never fully realised, although they did significantly influence Irish political life: 86.

${ }^{22}$ Select Constitutions of the World was a collection of constitutions that the Acting-Chairman of the Constitution Committee of 1922 prepared for the information of the Dáil in its capacity as constituent assembly. The collection was updated and republished in 1934 by B. Shiva Rao, in Select Constitutions of the World (Madras, 1934). As Kissane (2011: 31) notes, given the backgrounds of the drafters in British administration and law: '...the broad frame of reference was noteworthy'.
} 
over property and State powers over private property and natural resources. Further property issues, including land policy, were covered in Articles 63 (which limited rights of private property over natural resources in the public interest and asserted a claim of State ownership over all unappropriated natural resources) and 64(1) (which provided: '[o]wnership, inheritance, distribution and use of land are superintended by the State, so as to ensure to every citizen a healthy residence, and to secure an efficient exploitation of the soil and in the interests of the community'). Article 64 provided that landholders had a duty to use land efficiently, and that all increases in land value not attributable to the labour or expenditure of the landholder (JS Mill's 'unearned increment') would accrue to the community rather than the holder.

The Provisional Government selected Draft $\mathrm{B},{ }^{23}$ and chief negotiator Michael Collins took it to London for approval (Curran, 1980: 201). ${ }^{24}$ The British Government rejected the proposed Constitution, expressing particular concern with Article 1 in light of its assertion of sovereignty and the 'Soviet character' of its property clause (Mohr, 2008: 172). The Irish leadership drew up a revised Constitution, with an express statement of the Free State's coequal status within the Commonwealth and without draft Article 1's statements concerning property (Mohr, 2008: 172, Cahillane, 2014: 21). As a result of British intervention, and in the interests of bolstering the Free State's political independence, the Constitution of the Irish Free State (Saorstát Éireann) Act 1922 did not ultimately include a property clause, except with respect to property already vested in the State, and natural resources (Article 11). The rejection of the draft clause by Britain was another important turning point for Irish land law. With England in the midst of its own conveyancing revolution, the impact of its neighbour, former colony and departing member of the United Kingdom's choice of property norm appears to have retained some political salience. While it would be speculative to imagine how Irish law (and society) might have developed if the draft property clause had not been rejected by the British Government in 1922 - or if the adoption of a 'socialist' property clause in Ireland would have impacted on English thought - this episode serves as a reminder of the role of events in setting the frame of property values within which law develops. As we discuss in section (c) below, by the time the opportunity to define property constitutionally recurred in 1937, the property context in Ireland had shifted once again.

\section{(b) England and the 1925 legislation}

The early 1920s were also a formative period for modern English land law, culminating in the ' 1925 legislation', ${ }^{25}$ the collection of consolidating statutes which constructed the 'modern' framework for land ownership and transfer on principles of certainty, simplicity and alienability (or 'free trade') of land. The 1925 legislation was highly successful, both in creating a comprehensive structural framework and in embedding liberal-capitalist "property values' to govern land. It promoted the interests of purchasers and capital holders, according 'trump value' to strong property rights, and prioritising legal over equitable, registered over

\footnotetext{
${ }^{23}$ NAI Department of an Taoiseach File S/8953.

${ }^{24}$ Although: "[t]he Irish Government, as was expressly admitted by the British Colonial Secretary in the House of Commons, was under no obligation to consult the British Cabinet. Inasmuch, however, as the Constitution represented an implementation of the Treaty and would, therefore, require to be confirmed by the British Parliament, it was obviously expedient prior to the publication of the Draft to secure an assurance from the British Government that it was regarded by Great Britain as conforming to the terms of the Treaty': (Kohn, 1932: 78).

${ }^{25}$ Law of Property Act 1925, Land Charges Act 1925, Land Registration Act 1925, Settled Land Act 1925, Administration of Estates Act 1925.
} 
unregistered, formal over informal claims. Architect of the legislation, Lord Birkenhead, wrote that the policy of the framers was:

'...to assimilate the law of real and personal estate and to free the purchaser from the obligation to enquire into the title of him from whom he purchases, any more than he would have to do if he were buying a parcel of stock. ${ }^{26}$

The aim was to encourage investment and trade by promoting the security of individual rights. The 1925 legislation represented a decisive break from the past, sweeping away many of the features associated with the aristocratic, status-based land system, in favour of capitalist, contract-based free trade in land (Cowan et al, 2016: ch 3). It reduced the number of legal estates and interests, with others taking effect only in equity; introduced systems of land charges registration (for unregistered land) and land registration (registered land) to manage equitable interests; extended the concept of 'overreaching' to reduce risk for purchasers; and reformed the law of co-ownership and mortgages. Land was re-configured as a fungible commodity, as readily exchangeable as any other.

The ideology of the 1925 legislation was diametrically opposed to the Irish position, as reflected in the (British Government-rejected) Article 1 of the proposed 1922 Constitution. While the English policy prioritised the commercial trade and exchange value of land, the Irish provision highlighted its social and use value; where the central achievement of the English reforms was to assimilate land with other forms of property, enabling 'free trade in land' by making it as easily transferable as any other capital asset, the political consensus in Ireland viewed land as bearing a distinctive, material value, which accrued to the community as a national asset. The drafting of the 1922 Constitution coincided with the culmination of the programme of conveyancing reform, started by the Liberal government in 1906 and supported by the Conservative Party - which evolved its property policies from defence of the late-aristocratic agrarian status quo to support 'free trade' measures that (it was hoped) would enable small-holders to own their land; thus embracing the idea of ownership as a bulwark against radicalism that Thatcher would revive in 1979. While Irish land reform had a long history of state intervention - from conquest to leasehold enfranchisement - English land reform remained consistent with the dominant ideology of free market noninterventionism, entrusting the invisible hand (facilitated by the removal of legal encumbrances) to achieve land redistribution. The 1925 legislation has had a lasting impact on English land law: while its status is legislative rather than constitutional, it has demonstrated a 'quasi-constitutional' resilience, even in the face of subsequent legislation that explicitly set out to reverse its effects. ${ }^{27}$

\section{(c) Bunreacht na hEireann - The 1937 Irish Constitution}

By the mid-1930s, political energy in Ireland was focused on breaking free of English control, including attempts to break the cycle of economic dependency through failed quests for economic self-sufficiency, and renewed interest in constitutional reform. During the Anglo-Irish Trade War (1932-1938) the Irish government withheld the payment of land annuities ('debt' owed to the British Treasury linked to financing of Irish leasehold enfranchisement). The British government retaliated by imposing trade quotas and tariffs,

\footnotetext{
${ }^{26}$ Letter to The Times, 15 December, 1920.

${ }^{27}$ The Trusts of Land and Appointment of Trustees Act 1996 replaced the 'trust for sale' (Law of Property Act 1925) on co-owned land with a 'trust of land'; however, judicial applications of the 1996 Act have interpreted provisions governing the trust of land in line with the 1925 provision (Fox, 2000).
} 
until the dispute was resolved by a one-off payment of $£ 10$ million, from Ireland to the British government (O'Grada, 1997: 5-6). Kissane claimed that: '[b]y 1937 the Irish state was diplomatically isolated, dependent on protectionist economic policies, and culturally defensive' (2011: 57). With an agenda to move Ireland out of the shadow of English political power, the President of the Executive Council and Leader of the governing Fianna Fáil party, Eamon de Valera, proposed drafting a new Constitution to be considered by the Irish people through a referendum (Hogan, 1997: 347).

De Valera's approach to constitutional reform was characterised as an Irish version of the 'Whig' tradition (exported from Britain and Europe to North America): founded on belief in a virtuous citizenry who would be amenable to restraints on individual rights (Kissane, 2011: 58). Nevertheless, the complexities of Irish cultural attitudes towards private property presented a challenge for the drafters of the new Irish Constitution, who were required to balance the demand for security of possession with the need for the State, through the Land Commission, to continue the work of redistributing land to achieve a socially just and economically sustainable property system. ${ }^{28}$ Land redistribution remained a key political issue, both nationally and locally:

'Acquisition and division, with all their threats and promises, ensured that after independence Irish society remained animated by land issues. Rural society remained in a state of continual flux where some people lived with the hope that the government, through the working of the Land Commission, would improve their social and economic situation by giving them more land, while others lived with the fear and the insecurity that the Commission might compulsorily acquire their land.' (Dooley, 2004: 229)

Against this backdrop, political discourse shifted away from the socialist ideals that influenced Drafts A and B of the 1922 Constitution, towards the approach adopted in Draft C: protecting private ownership, but in the context of a detailed, explicit framework for Stateintervention for social and economic purposes, including significant powers to limit property rights.

While the 1925 legislation reflected free trade and the 'entrepreneurial ideal', Catholic social teaching was a significant influence on the 1937 Constitution (Keogh and McCarthy, 2005), with references in the drafting materials to Rerum Novarum ${ }^{29}$ and Quadragesimo Anno, ${ }^{30}$ Papal Encyclicals issued by Pope Leo XIII and Pope Pius XI respectively. For Leo XIII, the propagation and protection of private ownership was the favoured means of ensuring the sustenance of all men, peaceful relations between the classes, and the efficient use of natural resources; natural rights to private ownership required that the State could limit, but not

\footnotetext{
${ }^{28}$ Ronan Keane noted: '...the mightiest social revolution ever to take place in Ireland, the end of landlordism as the dominant form of ownership of agricultural land, had been fuelled by the vast powers of expropriation vested in the Irish Land Commission. De Valera and those who framed the Constitution with him had no intention of allowing those major social changes to be rolled back, or similar reforms to be impeded in the future, and hence the second section of the Article 43, permitting such inroads on private property rights where they were justified by the requirements of 'social justice' and 'the common good' (Keane, 1988: 138). The work of the Commission had other significant implications for the development of Irish land law on the ground, as - through the redistribution process - it carried out the costly, complex work of clarifying boundaries, title, and third party rights in respect of transferred land (Dooley, 2004: 9).

${ }_{29}$ (Pope Leo XIII, 15 May 1891). Text of Rerum Novarum obtained at http://www.papalencyclicals.net/Leo13/113rerum.htm

${ }^{30}$ (Pope Pius XI, 15 May 1931). Text obtained at: http://www.papalencyclicals.net/Pius11/P11QUADR.HTM.
} 
abolish, private property. In Quadragesimo Anno, Pope Pius XI stressed the need for balance between individualism and collectivism:

'...twin rocks of shipwreck must be carefully avoided. For, as one is wrecked upon, or comes close to, what is known as 'individualism' by denying or minimizing the social and public character of the right of property, so by rejecting or minimizing the private and individual character of this same right, one inevitably runs into 'collectivism' or at least closely approaches its tenets.' (Quadragesimo Anno: [46])

Dr John Charles McQuaid, a key religious advisor on the drafting of the 1937 Constitution, submitted numerous draft articles to de Valera that drew heavily on Rerum Novarum and Quadragesimo Anno. ${ }^{31}$ Rev. Edward Cahill ${ }^{32}$ and the Jesuit Committee that advised de Valera drew upon the Papal Encyclicals, as well as other Catholic constitutions in Europe, including the Austrian Constitution of 1934 and the Polish Constitution of $1921 .^{33}$ Echoing the approach adopted in 1922, other constitutions, including those influenced by Catholic social teaching, were considered in the drafting process. ${ }^{34}$

Archival records of the drafting process reveal that the initial inclination of those preparing the new Constitution was to propose a constitutional provision that would treat private property rights, and the principles of social policy that should limit such rights, together in one general provision dealing with economic life within the State (Walsh, 2011). This would have required that the exercise of property rights be considered in the broader social context, in light of the effects that such exercise could have on society as a whole, particularly on vulnerable members of the community. Private ownership and social justice would be balanced by protection of the institution of private ownership and the individual rights flowing therefrom, while also giving the State a clear mandate to restrict the exercise of property rights on the basis of constitutional guidance on the meaning of social justice. In this way, the opportunity to own private property could be strongly protected - a salient goal given the memory of the Penal Laws and the contemporary political backdrop in Europe in 1937, as the rise of communism pushed Catholic property ideology towards private ownership (Bromage and Bromage, 1940, Walsh, 2011) - but without creating the kind of absolute property rights that would be an impediment to necessary social and economic reforms. As late as March 1937, the format for the property article grouped private property guarantees alongside delimiting principles of social policy. ${ }^{35}$

However, when a draft Constitution was published on 1 May 1937, it protected private property rights in the terms now contained in Articles $40.3 .2^{36}$ and $43^{37}$ of the 1937

\footnotetext{
${ }^{31}$ Archival documentation, University College Dublin: UCDAD/P150/2395.

${ }^{32}$ Documentation contained at UCDAD/P150/2393, setting out Cahill's submissions. See also Faughnan (1988) who highlights the extent to which Cahill acted as spokesman for a wider Jesuit committee.

${ }^{33}$ Donal Coffey argues persuasively that Article 99 of the Polish Constitution was influential at an early stage in the drafting of the property rights provisions, although its influence was attenuated in later versions; unpublished manuscript, on file with the authors, Coffey: 2018. However, Kissane argues that the Polish Constitution's statement of a State aim of wide distribution of private productive property did influence the Constitution as adopted, albeit in the Directive Principles of Social Policy in Article 45, rather than in the property rights provisions: (Kissane, 2011: 66).

${ }^{34}$ Rao's Select Constitutions of the World was again a key source in respect of foreign constitutions.

${ }^{35}$ NAI Department of an Taoiseach File S/9715 A. The same draft appears to be contained in de Valera's papers, at UCDAD/P150/2401.

${ }^{36}$ Article 40.3. $2^{\circ}$ states: 'The State shall, in particular, by its laws protect as best it may from unjust attack and, in the case of injustice done, vindicate the life, person, good name, and property rights of every citizen.'

${ }^{37}$ Article 43 provides:
} 
Constitution. The delimiting principles of social policy - separated out in Article $45^{38}$ for the exclusive cognisance of the legislature - articulated the need to promote the welfare of all, with justice and charity as guiding principles, and the need for material resources to be distributed to secure the common good. These principles also enshrined de Valera's vision for a strong agrarian economy, with as many families settled on the land as was practicable; and recommended controls on credit and competition, and a commitment to protecting the needs of vulnerable people.

The separation of property rights guarantees and principles of social policy, and the decision to make the delimiting principles non-cognisable by the courts, appears to have been prompted by political concerns about the possibility that the social policy principles would be relied upon by individuals in court to establish positive rights, rather than any desire to weaken the power of the State to restrict the exercise of individual property rights (Walsh, 2011: 93-97). The constitutional protection of private ownership reflected the Irish cultural commitment to private property, rooted in the historic struggle for land ownership, and in the entrenchment of the 'possessor principle' through decades of land redistribution. Notwithstanding this commitment to private ownership, the 1937 Constitution enshrined a fundamentally socially-oriented conception of property. The institution of private ownership, and some of its core features (powers of alienation and bequest) were guaranteed in Article 43.1, but the individual right to exercise property rights was qualified by Article 43.2, which

1. ' 1 ' The State acknowledges that man, in virtue of his rational being, has the natural right, antecedent to positive law, to the private ownership of external goods.

$2^{\circ}$ The State accordingly guarantees to pass no law attempting to abolish the right of private ownership or the general right to transfer, bequeath, and inherit property.

2. $1^{\circ}$ The exercise of the rights mentioned in the foregoing provisions of this article ought, in civil society, to be regulated by the principles of social justice.

$2^{\circ}$ The State, accordingly, may as occasion requires delimit by law the exercise of the said rights with a view to reconciling their exercise with the exigencies of the common good.'

${ }^{38}$ Article 45 provides:

1. 'The State shall strive to promote the welfare of the whole people by securing and protecting as effectively as it may a social order in which justice and charity shall inform all the institutions of the national life.

2. The State shall, in particular, direct its policy towards securing:-

$1^{\circ}$ that the citizens (all of whom, men and women equally, have the right to an adequate means of livelihood) may through their occupations find the means of making reasonable provision for their domestic needs.

$2^{\circ}$ that the ownership and control of the material resources of the community may be so distributed amongst private individuals and the various classes as best to subserve the common good.

$3^{\circ}$ that, especially, the operation of free competition shall not be allowed so to develop as to result in the concentration of the ownership or control of essential commodities in a few individuals to the common detriment.

$4^{\circ}$ that in what pertains to the control of credit the constant and predominant aim shall be the welfare of the people as a whole.

$5^{\circ}$ that there may be established on the land in economic security as many families as in the circumstances shall be practicable.

3. $1^{\circ}$ The State shall favour and, where necessary, supplement private initiative in industry and commerce.

$2^{\circ}$ The State shall endeavour to secure that private enterprise shall be so conducted as to ensure reasonable efficiency in the production and distribution of goods and as to protect the public against unjust exploitation.

4. $1^{\circ}$ The State pledges itself to safeguard with especial care the economic interests of the weaker sections of the community, and, where necessary, to contribute to the support of the infirm, the widow, the orphan, and the aged.

$2^{\circ}$ The State shall endeavour to ensure that the strength and health of workers, men and women, and the tender age of children shall not be abused and that citizens shall not be forced by economic necessity to enter avocations unsuited to their sex, age or strength.' 
enshrined the State's power to restrict the exercise of such rights to secure ; the principles of social justice' and 'the exigencies of the common good'. While all individuals were afforded a constitutionally guaranteed opportunity to participate in a private property system, the rights flowing from the operation of that system to individuals were expressly subject to limitation in the public interest. This crystallised, within the text of the Constitution, the tension between the security afforded by property rights, on the one hand, and resistance to absolutist conceptions of ownership, as impediments to social justice, on the other. It reflected the culmination of a complex interaction of local, national and international factors, including the legacy of the Famine and the Penal Laws, the association of land reform with independence and the assertion of national identity, the redistribution of land for economic reasons, the continuing influence of informal, local land-use practices as key ordering principles, the role of the Catholic church and the European political context. Nevertheless, the impact of these social policy principles in delimiting property rights was significantly weakened by the late decision to restructure Articles 43 and 45, moving the social justice principles out of the property clause (Article 43) and designating these as non-justiciable 'Directive Principles of Social Policy' in Article 45 (Walsh, 2011: 108-109).

\section{(4) Conclusions}

English and Irish land law can be understood as two pieces of a puzzle: a pair of parallel helices, intertwined around shared axes of the English common law (and its 'first adventure' in Ireland), and the politics of land reform; structurally connected through the British-Irish constitutional and economic relationship, each following a distinctive path, but shaped, at key moments, by their duality. The impact of the British-Irish relationship on Irish land law is indisputable. Ireland and Britain continued to be closely connected in political and economic terms in the post-colonial context, influencing Irish tenure relationships, land reform policies, property ideologies, and state-making processes. The role of English property ideologies, founded in liberal individualism and laissez-faire economics, is clear, with the baseline conception of ownership applied in Irish law mirroring the liberal conception of the "standard incidents of ownership' famously articulated by Tony Honoré (1961: 107). While Ireland has, since the Famine-era at least, looked beyond the English comparator (to the US, and then to the Constitutions of the World) in formulating its national approach to real property law and politics, the influence of the English common law has remained a key feature in Ireland's complex land law culture. However, Irish land law remains characterised by a continuous process of legislative, judicial and administrative balancing of the 'individual' and 'social' aspects of property. A myth of absolutism in respect of property coexists with a relatively uncontentious reality of deep State intervention in regulating the exercise of property rights. Irish land law has also been influenced by the legacy of Ireland's reactions against British ideologies of property and sovereignty in Empire, the Irish Land Wars and the central importance of land in the campaign for national independence, with important and enduring connections between property, independence and national identity.

The influence of the British-Irish relationship on English land law is not often acknowledged in English legal discourse. We argue that comparative analysis of the foundational commitments of English and Irish land law brings each jurisdiction's approach into clearer relief, revealing the ideological foundations of each system against the relief of a close neighbour with centuries of connected-but-different legal culture, and the complexities generated by each jurisdiction's lived experience in regulating the use and ownership of land. Perhaps most starkly, our analysis demonstrates why land law cannot be neatly or simply understood as 'individualistic' or 'absolutist' on the one hand, or 'communitarian' or 
'progressive' on the other hand - land law regimes are influenced by multiple competing, and at times overlapping, property ideologies; shaped not only by the persuasive power of normative ideas but by the events and externalities which contextualise the politics of property law. Accordingly, this comparative project is particularly well-suited to a 'midrange' approach, which focuses on the space between the abstract normativity of 'grand theories', and the 'earthy pragmatism' of doctrinal land law, seeking to better understand the practical, political, social and symbolic meaning and content of the law as it has evolved in local contexts. A mid-range view can reveal the complex, multi-scalar factors that shape the path by which land law evolves, reforms, or is re-imagined in a particular jurisdiction. By seeking not to build a 'general and definitive framework', but rather to investigate specific problems through an 'evolving and provisional framework' (Merton, 1949: 453), mid-range analyses such as that undertaken in this article reveal the range of influences on land law. These include global and local forces, from world-system movements (for example, the influence of European political developments in 1937 on the Irish Constitution) or bi-lateral relationships (for example, the impact of the Irish land wars on the English land reform movement, or the ongoing trade dependency between Britain and Ireland into the twentieth century), to complex local political, economic, social and cultural contexts that determine whether, and when, the status quo prevails, or a tipping point for land reform is reached.

One key difference between Ireland and England is the route through which their land law systems - and the property ideologies that shaped, and are sustained, by it - were formed. The Irish system was forged from a popular political movement to reclaim territory and sovereignty from Britain, and refined through the processes of state-making surrounding the 1922 and (particularly) 1937 Constitutions. These processes (echoing the explicit role of property/sovereignty clauses in constitution drafting processes across Europe and elsewhere in the $19^{\text {th }}$ and $20^{\text {th }}$ centuries) required the newly-formed state to work through the complex legacies of Ireland's property ideologies, generated through the experiences of the common law, Penal laws, and land reform, and to reach a reconciled (and workable) position that reflected the collective will of the Irish people. In England, there has been no comparable revolutionary moment to prompt the formulation of a property perspective that is reflective of, and - crucially - reconciles, factors of national identity, economic ideology, political philosophy and the lived experiences of owners, occupiers and others outside these categories. The ideologies of private property and sovereignty - with their roots in the justification of the British Empire's governance of colonised territories and, later, nineteenth century free-market individualism and the Victorian social morality of individual responsibility, hard work and entrepreneurship - were not disrupted by any effective popular land reform movement. Rather, the 1925 legislation was a 'conveyancing revolution', managed by the political classes (following the conversion of the Conservative Party to free trade reform in the early twentieth century, as a bulwark against socialist revolution) and led by legal professionals; extending the ideals of the free market from personal property law to land law.

Notwithstanding the political heat of the British-Irish relationship in which each jurisdiction's distinctive perspective was forged, comparative analyses of English and Irish land law also highlight the role of pragmatism and concessions in the evolution of these distinctive but related regimes. Ireland's 1937 Constitution, and the articulation of a distinctive constitutional property identity, was an important expressive moment for the independent state, but many of the 'cross-links' between the helices remained intact. The legacy of imported common law principles remains significant, both in terms of the general structure of the land law system, and the approach of Irish courts, including heavy reliance on English 
case-law in certain doctrinal contexts (for example, in the law of easements). This can be understood as a pragmatic move: as Dicey observed in the English case, radical reform of laws regulating land is challenging, 'because their amendment is a task of great technical difficulty' (1905: 232). It also reflects the paradox of the Irish land movement, which was its creation of a nation of owner-occupiers, including the recognition of property rights vested pre-Independence. As we noted in Part 3(d), above, land ownership was practically and symbolically important to the Irish people, notwithstanding the social and communitarian vision of property that emerged in the Irish constitutional context. Reconciling the elements of a hybrid legacy is a common challenge in post-colonial or new-constitutional contexts. Reflecting on the processes through which South African courts engaged with transformation - from apartheid-era 'common law orthodoxy', to a new approach under the post-apartheid Constitution - André van der Walt has argued that the transformation of property law under the new constitutional dispensation should not be understood as a linear process of replacing one (old) orthodoxy with another (new) orthodoxy: that, he argued would be 'setting our transformation sights too low' (2002: 271). A better approach, van der Walt advised, is to resist either orthodoxy in favour of 'integrative pluralism', an approach that subjects existing hierarchies or ideologies to continuous critical reflection. That insight finds further support in the Irish experience, which demonstrates the emergence of a complex cultural and legal attitude towards property in a post-colonial context, and where the home-grown desire distinct from the imported ideology - for appropriation and retention of the power and security associated with property rights was tempered by social justice commitments - also borne of the local context - which required that such rights would not be absolute but limited by the public interest.

This article provides a prolegomena for further comparative analyses of English and Irish land law. Our aim is to advance a framework for analyses of specific areas of doctrine or legislation, to encourage continuous critical reflection on a problem-by-problem basis, and attending to the contextual differences embedded below the surface of formal laws. Our working hypothesis for continuing this work is that while in some areas the jurisdictions are pragmatically aligned, so avoiding irresolvable or economically cumbersome conflicts, on many contentious issues the Irish and English approaches diverge in ways that reflect each regime's ideological priorities. For example, while English law requires that a leasehold term must be certain from the outset (Prudential Assurance v London Residuary Body [1992] 3 All ER 504; but see Bright, 1993); Irish law does not impose a 'certainty of term' requirement for leasehold estates (Land and Conveyancing Law Reform Act 2009, section 11(3)(c)). While the possibility for mortgagees to achieve out-of-court possession (Ropaigealach v Barclay's Bank plc [2000] QB 263; Horsham Properties Group Ltd v Clark [2009] 1 WLR 1255) and/or sale (Law of Property Act 1925, ss101-103; Horsham Properties v Clark \& Beech [2008] EWHC 2327 (Ch)) of mortgaged property has been criticised in the English context, attempts to close this loophole have not yet been successful; ${ }^{39}$ in contrast, out-of-court repossession by mortgagees has rarely been employed in the Irish context, and repossession by mortgagees without notice and an independent review process was recently declared to be unconstitutional in the Irish High Court. ${ }^{40}$ In the Land and Conveyancing Law Reform Act

\footnotetext{
39 In 2009, Andrew Dinsmore MP introduced the Ten-Minute Rule 'Home Repossession (Protection) Bill', proposing that a court order be required for mortgagees to exercise the power of sale; the Bill did not receive a second reading. The Ministry of Justice Consultation Paper, Mortgages: Power of Sale and Residential Property (2009), which advanced a similar proposal, was not implemented.

${ }^{40}$ Irish Life and Permanent v Duff [2013] 4 IR 96, where Hogan J laid down a requirement of "notice, foreseeability and independent determination of the objective necessity for yielding up of possession' primarily on the basis of the constitutional protection for the inviolability of the dwelling in Article 40.5 of the Irish
} 
2009 (LCLRA), the Irish legislature embraced a default requirement of judicial process for all non-consensual repossessions and sales by mortgagees (ss97, 100), tempering the mortgagee's power to recover its capital investment against the social justice of hardship to mortgagors (and their families). And in a move that shifted the balance of power from private control to the public or community interest (see Epstein, 1982), the Irish legislature accepted that positive obligations through freehold covenants are capable of running with the land (LCLRA, s49). Again, this proposition has been advanced by the English Law Commission, but not adopted (Law Commission, 2011). After extensive debate, the Irish legislature opted not to follow the English approach of barring legal tenancies in common and limiting the number of legal joint tenants in the 2009 Act, on the basis that concerns about fragmentation of title and efficiency that motivated the English approach had not, according to reports from Irish solicitors, created practical problems in Ireland, and on the basis of a concern to preserve owners' freedom to determine their manner of holding land. ${ }^{41}$ Similarly, the Irish legislature has not followed the English approach of effectively abolishing adverse possession under the Land Registration Act 2002 (Cobb and Fox, 2007). While the English reform had strong ideological and rhetorical drivers (Fox O'Mahony et al, 2014), the Irish approach is practice-focused and pragmatic in recognising the use of adverse possession as an informal means of passing title to land (usually agricultural) within families upon death (Wylie, 2013: 1046).

These divergences merit further analysis, which space has precluded in this article. The framework we have established presents two 'working hypotheses' to guide the next phase of this work. First, we suggest that greater weight is afforded to local factors and informal practices ('use value') in Irish land law; compared to the more bureaucratic ('exchange value') approach adopted in England, at least since 1925, and with heightened vigour since the Land Registration Act 2002. Irish land law has maintained a strong material focus on 'property as possession', while English land law has increasingly adopted a more conceptual approach, focused on 'property as right' (Gray and Gray, 1998: 15, 18-19, 27). Secondly, we contend that while the liberal common law conception of ownership continues to provide the 'base-line' for Irish land law, the Irish lived experience has generated resistance to absolutist conceptions of property rights, as crystallised in the 1937 Constitution, prompting the evolution of a distinctive approach to property. This approach resists the polarising orthodoxy of 'grand theories' (libertarian or communitarian), but tends towards an ongoing process of legal and political negotiation towards a middle-ground position: respect for private property rights, appropriately delimited by social justice considerations. In this respect, and notwithstanding its common law foundations, Ireland can trace common heritage with those European states whose constitutions embedded social democratic visions of property, perhaps most notably, the German 'social obligation' clause (see Allen, 2010: 1058-1065). Ireland's continuous engagement with European influences - from the formulation of the 1922 and 1937 Constitutions to its participation as an EU member state after 1973 - provided an important counter-influence to the inherited common law as Irish law evolved after independence. This cosmopolitanism has implications that merit further exploration with respect to Ireland's approach (compared to England's) to aspects of property law that are brought under European Union (for example, mortgage credit) or European Convention on

Constitution, although note also the decision of the High Court in Fennell $v$ Creedon [2015] IEHC 711, rejecting the contention that this requirement applied to the appointment of a receiver by a mortgagee.

${ }^{41}$ See Irish Law Reform Commission (2004): Ch 6, at 6.02-6.05 especially. However, the 2009 Act did prohibit unilateral severance of joint tenancies, instead conferring powers on courts to adjudicate upon severance applications taking account of a range of factors, including the need to achieve fairness between co-owners: Land and Conveyancing Law Reform Act 2009, ss. 30 and 31. 
Human Rights (for example, adverse possession, mortgage and tenant repossession) jurisdiction. As the British-Irish relationship comes under pressure once again in the context of the 'Brexit' negotiations, comparative analyses of property law in Ireland and England provide a valuable lens through which to better understand the land law of both jurisdictions, casting into sharper relief the role of competing ideologies in shaping doctrinal land law.

\section{References}

Alexander GS, Peñalver EM, Singer JW and Underkuffler LS (2009) A statement of progressive property. Cornell Law Review 94: 743-744.

Allen T (2010) Liberalism, social democracy and the value of property under the European Convention on Human Rights. International and Comparative Law Quarterly 59: 1055-1078. Anderson JS (1992) Lawyers and the Making of English Land Law 1832-1940. Oxford: Clarendon Press.

Arneil B (1996) John Locke and America: The Defence of English Colonialism. Oxford: Clarendon Press.

Atiyah PS (1979) The Rise and Fall of Freedom of Contract. Oxford: Oxford University Press.

Baron JB (2010) The contested commitments of property. Hastings Law Journal 61: 917968.

Bew P (1979) Land and the National Question in Ireland, 1858-82. Dublin: Gill \& Macmillan.

Boylan TA and McDonough T (1998) Dependency and Modernization: Perspectives from the Irish Nineteenth Century. In: Foley $\mathrm{T}$ and Ryder $\mathrm{S}$ (eds) Ideology and Ireland in the Nineteenth Century. Dublin: Four Courts Press, pp. 113-129.

Bright, S (1993) Uncertainty in leases - Is it a vice? Legal Studies 13: 38-53

Bromage AM and Bromage MC (1940) The Irish Constitution: A Discussion of Its Theoretical Aspects. The Review of Politics 2: 145-166.

Bull P (1996) Land, Politics and Nationalism: A Study of the Irish Land Question. Dublin: Gill and Macmillan.

Cahillane L (2014) An Insight into the Irish Free State Constitution. American Journal of Legal History 54: 1 -38.

Chubb B (1970) The Government and Politics of Ireland. $2^{\text {nd }} \mathrm{ed}$, London: Longman.

Cliffe Leslie TE (1870) Land Systems and Industrial Economy of Ireland, England and Continental Countries. London: Longman.

Cobb N and Fox L (2007) Living outside the system? The (im)morality of urban squatting after the Land Registration Act 2002. Legal Studies 27: 236-260.

Cobden R (1835) England, Ireland and America. London: James Ridgeway \& Sons.

Coffey D (2018) Drafting the Irish Constitution 1935-1937: Transational Influences in InterWar Europe (forthcoming, London: Palgrave and Macmillan, 2018) (manuscript on file with authors).

Collinson Black RD (1960) Economic Thought and the Irish Question 1817-1870. Cambridge: Cambridge University Press.

Cowan D, Fox O'Mahony L and Cobb N (2016) Great Debates in Land Law. $2^{\text {nd }}$ edn. London: Palgrave Macmillan.

Cragoe M and Readman, P (eds) (2010) The Land Question in Britain, 1750-1950. London: Palgrave Macmillan.

Cragoe M (2010) “A Contemptible Mimic of the Irish": The Irish Land Question in Victorian Wales. In: Cragoe M and Readman P (eds) The Land Question in Britain, 1750-1950. London: Palgrave Macmillan. 
Crotty R (1966) Agricultural Production: Its Volume and Structure. Cork: Cork University Press.

Cullen LM (1987) An Economic History of Ireland since 1660. London: Batsford Ltd.

Curran JM (1980) The Birth of the Irish Free State 1921-1923. Alabama: University of Alabama Press.

Daly M (1986) The Famine in Ireland. Dundalk: Dundalgan Press.

Davidson NM and Dyal-Chand R (2010) Property in Crisis. Fordham Law Review 78: 16071660

Deane P and Cole WA (1969) British Economic Growth, 1688-1959. Cambridge: Cambridge University Press.

Delaney VTH (1959) Irish and Scottish Land Resettlement Legislation. International and Comparative Law Quarterly 8: 299-319.

Devon Commission (1845) Report from her Majesty's Commissioners of Inquiry into the State of the Law and Practice in Respect of Occupation of Land in Ireland. Dublin: A Thom.

Directorate-General for Internal Policies (DGIP) (2017) Research for AGRI Committee EU-UK agricultural trade: state of play and possible impacts of Brexit. European Union.

Dicey AV (1905) The paradox of land law. Law Quarterly Review 21: 221-232.

Dixon MJ (2010) Modern Land Law . 7th edn. London: Routledge.

Dooley T (2004) The Land for the People: The Land Question in Independent Ireland. Dublin: UCD Press.

Dunning WA (1892) Irish Land Legislation since 1845. Political Science Quarterly 7: 57-79.

Edgeworth B (2007) Rural Radicalism Restrained: The Irish Land Commission and the Courts (1933-1939). Irish Jurist 42: 1-28.

English R (2000) Socialist Republicanism in Independent Ireland 1922-49. In: Cronin M and Regan JM (eds) Ireland. London: Palgrave Macmillan.

Epstein R (1982) Notice and Freedom of Contract in the Law of Servitudes. Southern California Law Review 55: 1353-1368.

Farrell B (1971) The Drafting of the Irish Free State Constitution: III. Irish Jurist 6: 111-135.

Faughnan S (1988) The Jesuits and the Drafting of the Irish Constitution of 1937. Irish Historical Studies 26: 79-102.

Fox L (2000) Living in a policy state: from trust for sale to trust of land. Liverpool Law Review 22: 59-88.

Fox O'Mahony L (2014) Property Outsiders and the Hidden Politics of Doctrinalism. Current Legal Problems 67: 409-445.

Fox O'Mahony L, O'Mahony D and Hickey R (eds) (2014) Moral Rhetoric and the Criminalisation of Squatting: Vulnerable Demons? London: Palgrave Macmillan.

Garvan T (1996) 1922: The Birth of Irish Democracy. Dublin: Gill \& Macmillan.

Gray K and Gray SF (1998) 'The Idea of Property in Land. In: Bright S and Dewar JK (eds)

Land Law: Themes and Perspectives. Oxford: Oxford University Press, pp.15-51.

Hancock WN (1847) On the Use of the Doctrine of Laissez-Faire, In Investigating the Economic Resources of Ireland. Dublin Statistical Society Transactions 1: 3-17.

Hancock WN (1848) On the Economic Causes of the Present State of Agriculture in Ireland, Part I: Legal Impediments to the Transfer of Land. Dublin Statistical Society Transactions 18.

Hancock WN (1850) Impediments to the Prosperity of Ireland. London: Simms \& McInture. Hancock WM (1860a) On the Bothy System of Lodging Farm Labourers in Scotland: Its Violation of the Family Principles, Its Condemnation by the Free Church of Scotland, the Conclusions to be Deducted from the Facts Stated, and Their Application to Ireland. Journal of the Dublin Statistical Society 375-381. 
Hancock WM (1860b) The Effects of the Employment of Women in Occupations Attended with Publicity, as Illustrated by the Result of the Factory System at Bradford. Journal of the Dublin Statistical Society 439-445.

Hogan G (1997) The Constitution Review Committee of 1934. In: Muircheartaigh F Ó (ed) Ireland in the Coming Times - Essays to celebrate T.K. Whitaker's 80 Years. Dublin: IPA.

Honoré AM (1961) Ownership. In: Guest AG (ed) Oxford Essays in Jurisprudence First Series. Oxford: Oxford University Press, pp.342-369.

Hoppen KT (1992) Ireland since 1800: Conflict and Conformity. London: Longman.

Howe A (2010) The "Manchester School" and Landlords: The Failure of Land Reform in Early Victorian Britain. In: Cragoe M and Readman P (eds) The Land Question in Britain, 1750-1950. London: Palgrave Macmillan.

Irish Law Reform Commission (2004) Reform and Modernisation of Land Law and Conveyancing Law. ILRC Consultation Paper 34-2004. Ireland: The Law Reform Commission.

Irish Law Reform Commission (2005) Reform and Modernisation of Land Law and Conveyancing Law. ILRC Report 74-2005. Ireland: The Law Reform Commission.

Katz L (2008) Exclusion and Exclusivity in Property Law. University of Toronto Law Journal 58: 275-315.

Keane Mr Justice (1988) Property in the Constitution and in the Courts. In: Farrell B (ed) Dev's Constitution and Ours. Dublin: Gill and MacMillan, pp.. 137-151.

Kelly JM (1967) Fundamental Rights in the Irish Law and Constitution. Dublin: Allen Figgis \& Co Ltd.

Kenny M (2007) Standing Surety in Europe: Common Core or Tower of Babel? Modern Law Review 70: 175-196.

Keogh D and McCarthy A (2005) The Catholic Church and the Writing of the 1937 Constitution. History Ireland 13: 36-41.

Keogh D and McCarthy A (2007) The Making of the Irish Constitution 1937. Dublin: Mercier Press.

Kinealy C (1994) This Great Calamity: The Irish Famine 1845-52. Dublin: Gill \& Macmillan.

Kinealy C (1997) A Death-Dealing Famine: The Great Hunger in Ireland. London/Chicago: Pluto Press.

Kissane B (2011) New Beginnings: Constitutionalism and Democracy in Modern Ireland. Dublin: UCD Press.

Kohn (1932) The Constitution of the Irish Free State. London: George Allen \& Unwin Ltd.

Koskenniemi M (2017) Sovereignty, Property and Empire: Early Modern English Contexts. Theoretical Inquiries in Law 18: 355-389.

Law Commission (2011) Making Land Work: Easements, Covenants and Profits à Prendre. Law Commission No 327, HC 1067. London: TSO.

Lee JJ (1989) Ireland 1912-1985. Cambridge: Cambridge University Press.

MacNiocaill G (1972) The Contact of Irish and Common Law. Northern Ireland Legal Quarterly 23: 16-23.

Maine HS (1861) Ancient Law. London: JM Dent.

Mamdani M (1996) Citizen and Subject: Contemporary Africa and the Legacy of Late Colonialism. Princeton: Princeton University Press.

McDonough T and Slater E (2005) Colonialism, Feudalism and the Mode of Production in Nineteenth-Century Ireland. In: McDonough T (ed) Was Ireland a Colony? Economics, Politics and Culture in Nineteenth-Century Ireland. Dublin: Irish Academic Press. 
McDonough T, Slater E and Boylan T (2005) Irish Political Economy Before and After the Famine. In: McDonogh T (ed), Was Ireland a Colony? Economics, Politics and Culture in Nineteenth-Century Ireland. Dublin: Irish Academic Press.

Merrill TW and Smith HE (2007) The Morality of Property. William and Mary Law Review 48: 1849-1895.

Merrill TW (1998) Property and the Right to Exclude. Nebraska Law Review 77: 730-755.

Merton RK (1949) On Sociological Theories of the Middle Range. In: Merton RK (ed) Social Theory and Social Structure. New York: Simon \& Schuster, The Free Press.

Mill JS (1868) England and Ireland. London: Longman, Green, Reader and Dyer.

Mill JS (1904) Principles of Political Economy with some of their Applications for Social Philosophy. London: Longmans, Green \& Co.

Ministry of Justice (2009), Mortgages: Power of Sale and Residential Property, Consultation Paper, CP55/09. London: Ministry of Justice.

Mohr T (2008) British Involvement in the Creation of the First Irish Constitution. Dublin University Law Journal 30: 166-186.

Njoh AJ (1998) The Political Economy of Urban Land Reforms in a Post-Colonial State. International Journal of Urban and Regional Research 22: 408-424.

O Grada C (1997) A Rocky Road: The Irish Economy Since the 1920's. Manchester: Manchester University Press.

O'Donnell D (2008) Property Rights in the Irish Constitution: Rights for Rich People, or a Pillar of Free Society? In: Carolan E and Doyle O (eds) The Irish Constitution - Governance and Values. Dublin: Thompson Round Hall, pp.412-430.

O'Hearn D (2005) Ireland in the Atlantic Economy. In: McDonough T (ed), Was Ireland a Colony? Economics, Politics and Culture in Nineteenth-Century Ireland. Dublin: Irish Academic Press, pp.3-26.

O'Malley E (1981) The Decline of Irish Industry in the Nineteenth Century. Economic and Social Review 13: 21-42.

O'Tuathaigh G (2013) Irish Land Questions in the State of the Union. In: Campbell F and T Varley T (eds) Land Questions in Modern Ireland. Manchester: Manchester University Press, pp.3-24.

Offer A (1981) Property and Politics 1870-1914. Cambridge: Cambridge University Press.

Penner J (1997) The Idea of Property in Law. Oxford: Oxford University Press.

Perkin HJ (1969) The Origins of Modern English Society 1780-1880. London: Routledge \& Kegan Paul.

Perkin HJ (1973) Land Reform and Class Conflict in Victorian Britain. In: Butt J and Clark IF (eds) The Victorians and Social Protest. Newton Abbot: David \& Charles (Holdings) Ltd, pp.177-217.

Peterson AC (2012) A Legal Standard for Post-Colonial Land Reform. Sustainable Development Law and Policy 13: 21-28; 60-63.

Poirteir C (ed) (1995) The Great Irish Famine Dublin: Dufour Editions.

Rao, B. Shiva (1934) Select Constitutions of the World. Madras: Madras Law Journal Press

Readman, P (2008) Land and Nation in England: Patriotism, National Identity, and the Politics of land, 1880-1914. London: Royal Historical Society.

Rosenberg, A (2013) Contract's Meaning and the Histories of Classical Contract Law. McGill Law Journal 59: 165-207.

Senghaas D (1985) The European Experience: A Historical Critique of Development Theory. Leamington Spa: Berg.

Singer JW (2009) Democratic estates: property law in a free and democratic society. Cornell Law Review 94: 1009-1062. 
Solow B (1971) The Land Question and the Irish Economy, 1870-1903. Cambridge: Harvard University Press.

Solow B (2013) The Irish Land question in a wider context. In: Campbell F and Varley T (eds) Land Questions in Modern Ireland. Manchester: Manchester University Press, pp.6579.

Steele, ED (1974) Irish Land and British Politics: Tenant-Right and Nationality, 1865-1870. Cambridge: Cambridge University Press.

Thompson FML (2002) Changing Perceptions of Land Tenure in Britain, 1750-1914. In: D Winch D and PK O'Brien PK (eds) The Political Economy of British Historical Experience, 1688-1914. Oxford: Oxford University Press/British Academy, pp119-138.

Van der Walt AJ (2002) Resisting Orthodoxy - Again. Thoughts on the Development of post-Apartheid South African Law. South African Public Law 17:259-278.

Van der Walt AJ and Walsh R (2017) Comparative Constitutional Conceptions of Property. In: Graziadei M and Smith L (eds) Comparative Property Law: A Research Handbook Cheltenham: Edward Elgar Publishing, pp.193-215.

Wagner DO (1953) Coke and the Rise of Economic Liberalism. The Economic History Review 6: 30-44.

Walsh B (1980) Foreword to J O'Reilly \& M Redmond, Cases and Materials on the Irish Constitution. Dublin: Incorporated Law Society of Ireland.

Walsh R (2011) Private Property Rights in the Drafting of the Irish Constitution: A Communitarian Compromise. Dublin University Law Journal 33: 86-115.

Wylie JCW (1997) Irish Land Law. $3^{\text {rd }}$ edn Dublin: Bloomsbury.

Wylie, JCW (2013) Irish Land Law. $5^{\text {th }}$ edn Dublin: Bloomsbury. 